\title{
ANALYSIS OF FACTORS INFLUENCING THE FAILURE OF HOT MIX ROAD TIMELINE ACHIEVEMENT IN TULUNGAGUNG DISTRICT
}

\author{
Azis Subandiyah, Jeremia Togi Dedy \\ Civil Engineering Majoring Construction Management, \\ National Institute of Technology, Malang, Indonesia \\ E-mail: cup.subandiyah@ymail.com \\ ORCID: 0000-0001-5963-4284
}

\begin{abstract}
This study is aimed to know factors influencing the failure of hot mix road timeline achievement and to discover the dominant factor so that appropriate strategies can be applied to overcome those factors. In this study, factor analysis and multiple linear regression analysis from the responses of questionnaire are used to analyze data. The questionnaire was distributed to 70 respondents from contractors, owners, and supervisors involved in hot mix road project in Tulungagung District in fiscal year of 2013. The findings of F-test shows that (X1), (X2), (X3), (X4), (X5), (X6), (X7), (X8), and (X9) factor affects simultaneously on the failure of hot mix road timeline achievement with $F_{\text {count }}=7.424>F_{\text {table }}=2.040$. However, regarding to partial t-test, factors that significantly influence the failure of hot mix road timeline achievement is Quality Control (X9) with $t_{\text {count }}=4.875>t_{\text {table }}=2.000$, Vehicle (X1) with $t_{\text {count }}=2.822>t_{\text {table }}=2.000$, and Environment $(X 2)$ with $t_{\text {count }}=2.141>t_{\text {table }}=2.000$. Moreover, it is found that the dominant factor is Quality Control factor (X9) with .375 as its coefficient $\beta$ value. In addition, to overcome the problem, controlling materials used carefully during the work and testing asphalt after the work are required.
\end{abstract}

\section{KEY WORDS}

Contractor, owner, consultant, quality.

One of the purposes of constructing hot mix road construction structure in Tulungagung District is to reduce stress or pressure due to vehicle wheel loads so that level of value received by soil supporting the structure can be achieved, (Epps, 2002). In stationary position, vehicle on the hardened surface creates direct load (static stress) on the pavement concentrated on small area between the wheel and pavement, (King et. al.,1994). On the other hand, in motion position, additional dynamic stress exists due to up and down movement of vehicle and uneven pavement, wind loads, and others. As a result, additional effect of load on the road surface while the vehicle moves will exist, (Eriksson et a., 2008)

In fact, highway flexible pavement has been designed to last up to 10 years, considering the growth of traffic every year (assuming the traffic growth is $2 \%$ ). Good quality road pavement is when it can reach the timeline based on the panned design with a number of planned vehicles crossing it, the implementation of road pavement construction is carried out properly, and all materials used are in accordance with standard requested in design specification and always used correctly, (Foltz, 1996).

However, not all road pavements can reach the timeline. For instance, in the implementation of hot mix road project in Tulungagung District, it is suspected that there are still many quality deviations. It can be seen in some hot mix road projects constructed in fiscal year of 2013 which are lightly, moderately, and even severely damaged which is estimated to reach $20 \%$ up to $40 \%$ of 10 -year timeline. As a result, the cost of maintenance required is quite a lot. Even at this time, road construction in certain points no longer meets the technical requirements. Repair and maintenance with the same construction, both surface and thickness, will always show damage again. In this case, there are some factors contributing to the failure of road timeline achievement, such as Vehicle, Work Environment, Human Resources, Work Implementation Method, Equipment, Land Condition, Materials, Financial, and Quality Control. 
In order to make the quality of hot mix road construction reach the timeline planned, some parties, such as owners, contractors, and consultant supervisors should be able to identify the factors earlier. Therefore, study about it should be conducted. However, different from the previous studies, this study was conducted in different location with different variables and indicators too in order to make the findings more applicative and competent. Besides, the findings are expected to be able to contribute to the Government of Tulungagung District in detecting causes of the failure of hot mix road timeline achievement.

\section{THEORETICAL FRAMEWORK}

Road, according to the Law Number 38 article 1 of 2004, is land transportation infrastructure involving all parts of road including complementary building and equipment intended for traffic, which is at ground level, above ground level, below ground and/ or water level, and above water level, except rail road tracks, lorry roads, and cable roads.

In the implementation, road construction should pass the plan adapted to the level of transportation growth of road in the area, especially on the appropriateness between load and traffic density with road carrying capacity, road network at the center of growth, center of production, and that which connects center of production with marketing area. In realizing the road construction in integrated manner, the policy of development by considering the characteristic of area, human resources potency, other sectors potency, and selection of appropriate technology are taken, (Alkass and Harris, 1991).

Highway construction should be constructed in such way so that it can hold traffic (vehicle) load crossing on it without any surface structure change. Along with the development of land transportation, especially motor vehicle including types and size, and number, traffic flow, safety, comfort, and carrying capacity of road pavement must be a concern, (El-Rayes and Kandil, 2005).

Road is the infrastructure connecting two or more locations consisting of some parts with certain purpose and function formed on a construction. Road construction generally consists of different layers of materials in accordance with properties used. In conclusion, there are three kinds of pavement construction, i.e. rigid, flexible, and composite.

Hot mix asphalt is a kind of mixture made to do road paving placed as the top layer construction (surface course) which receives loads directly from vehicle wheels crossing over it, (Bari, 2005). The composition of hot mix consists of coarse aggregate, fine aggregate, asphalt and rock ash (filler). Furthermore, the allowed temperature for hot mix asphalt is between $145^{\circ}-155^{\circ} \mathrm{C}$, while for spreading is $>95^{\circ}-145^{\circ} \mathrm{C}$.

Road quality is good when it can provide maximal service to road user based on development plan from comfort, safety, and durability aspect. Basically, the physic of road will experience damage progressively since the first time it is open for traffic. Therefore, protection and correlation is required.

Protection and correction are activities of road maintenance based on the exist regulation in Highways. Correction is aimed to restore the value of strength, safety level, comfort level, level of comfort of water permeability and water flow smoothness and applied to paved pavement which has been damaged with severe damage having local spread, such as collapsed holes, waves, crocodile crack, and mound. On the other hand, the characteristics of correction are carried out in accordance with events in the field, involving rural areas, which can be started from surface layer to ground, replacing or adding pavement part and providing construction value.

On the other hand, protection is aimed to maintain the value of strength, safety level, comfort level, surface permeability, water flow smoothness, which is applied on paved pavement surface showing symptoms of damaged road with wide spread degree, i.e. smooth crack, longitudinal crack, alligator crack, shrinking crack, swelling, corrugation, obesity (Public Works Department of Directorate General of Highways, 1983).

Timeline of road pavement is the number of year from the first time it is open for traffic until structural repair is required. During the timeline, road pavement maintenance should be continuously done, such as nonstructural coating which function is as a wear layer. 
Commonly, the timeline for new road pavement is 20 years, and for road improvement is 10 years. The timeline which is more than 20 years is no longer economical because the development of traffic is too large and difficult to obtain adequate accuracy (Alik, 2006).

Factor analysis is the extension of the main analysis component. Factor analysis is used to reduce data and to describe the correlation of some variables in a small number of factors. The variables are classified into several factors in which a factor will have high correlation, whereas its correlation with variables of other factors is relatively low.

Therefore, factor analysis aims to find out a way to summarize information in the original variable (initial) into a set of new dimensions or variations (factor) by defining structure through data summarization or data reduction. Factor analysis identifies relationship structure among variables or respondents by looking at the correlation among variables or respondents.

Multiple linear regression analysis in this study is used to test questions related to factors contributing to the failure of hot mix road timeline achievement in Tulungagung District and the dominant factor affecting the technique of analysis. Besides, it is used to test or analyze the impact of or correlation between independent variable with one or more variable (s). In the analysis technique, ANNOVA or F-test, t-test, and finding determination coefficient or $\mathrm{R}^{2}$ adjusted of the calculation will be done using SPSS based on multiple linear equation:

$$
Y=b_{0}+b_{1} X_{1}+b_{2} X_{2}+b_{3} X_{3}+b_{4} X_{4}+b_{5} X_{5}+b_{6} X_{6}+b_{7} X_{7}+b_{8} X_{8}+b_{9} X_{9}
$$

Where:

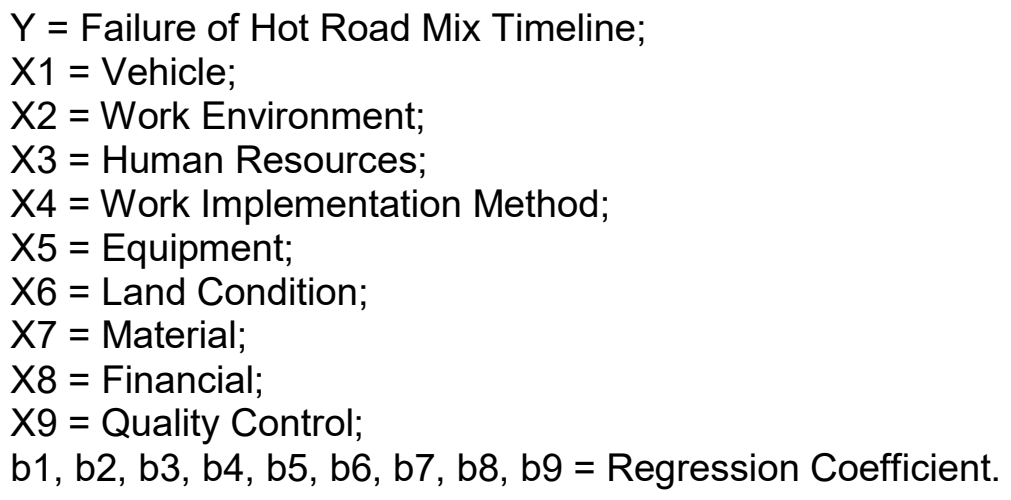

\section{METHODS OF RESEARCH}

Research is a science way to overcome a problem and to break the limit of human ignorance. Research is conducted through collecting and processing existing facts so that the facts can be communicated by researchers and the findings can be used for human life. In this study, descriptive study is conducted in which the researcher wants to know factors contributing to the failure of hot mix road timeline in Tulungagung District, to obtain dominant factor influencing it, and to determine strategies to overcome the factors.

To collect the data, direct observation and questionnaire were conducted. The questionnaire consists of asking opinion, experience and respondent behavior to obtain primary data. Furthermore, to obtain secondary data, any information from some institutions involved relating to the factors affecting failure of hot mix road timeline achievement. Then, factors based on some variables were determined to formulate question items which will be measured in a form of questionnaire.

This research was conducted on hot mix road in Tulungagung District in fiscal year of 2013 which could not reach the timeline.

Research Variables:

Independent variable $(X)$ consists of: Vehicle (X1), Work Environment $(X 2)$, Human Resources (X3), Work Implementation Method (X4), Equipment (X5), Land Condition (X6), Material (X7), and Financial (X8), Quality Control (X9). 
Dependent variable $(\mathrm{Y})$ : The failure of hot road mix timeline $(\mathrm{Y})$.

Data obtained from the questionnaire was processed to obtain some information in the form of table. The research of data processed is then used to answer the research questions. In processing the data, the data should be in regard to the purpose wanted to be achieved. Because the precise of analysis technique influences the result of the study, data analysis technique of this study are factor analysis and multiple linear regression analysis. The data obtained from questionnaire with range 1-5 of each variable is then repeated; thus each variable consisting of several indicators will produce only one score value which is analyzed using factor analysis and multiple linear regression analysis. Furthermore, data processing was conducted using Statistical Package and Service Solution (SPSS) 15 program for windows.

\section{RESULTS AND DISCUSSION}

Findings of Factor Analysis:

- Vehicle (X1) variable is formed by manifest variables consisting of the number of vehicle (X1.1), large vehicle with load exceeding tonnage (X1.2), and low vehicle speed (X1.3)

- Work Environment (X2) variable is formed by manifest variables consisting of road safety construction (X2.1), frequent rainfall (X2.2), surrounding condition (X2.3), and drainage condition (X2.4)

- Human Resources (X3) variable is formed by manifest variables consisting of PPTK Existence (X3.1), low quality Human Resource (X3.2), Difficulties in Finding Human Resources (X3.3), Human Resources with low coordination ability (X3.4), and Human Resources with low responsibility (X3.5)

- Work Implementation Method (X4) variable is formed by manifest variables consisting of discrepancy of work and existing ways (X4.1), specification deviation work (X4.2), and improper method while working (X4.3).

- Equipment (X5) variable is formed by manifest variables consisting of poor equipment condition (X5.1), equipment use neglecting its function (X5.2), equipment use neglecting its specification (X5.3), delay equipment delivery (X5.4), and limited number of equipment (X5.5).

- Land Condition (X6) variable is formed by manifest variables consisting of frequent landslide (X6.1), poor compaction (X6.2), and no repair on subgrade (X6.3).

- Material (X7) variable is formed by manifest variables consisting of material deficiencies (X7.1), material delivery lateness (X7.2), material changes (X7.3), material damaged in storage (X7.4), and material scarcity (X7.5).

- Financial (X8) variable is formed by manifest variables consisting of the delay of payment by contractors to workers (X8.1), late payment by contractors to suppliers (X8.2), and late payment by owners to contractors (X8.3).

- Quality Control (X9) variable is formed by manifest variables consisting of material (X9.1) and none asphalt test (X9.2).

- Variables of hot mix road timeline failure $(Y)$ are formed by manifest variable consisting of: road damage rate (Y1.1) and timeline toward road damage (Y1.2).

Findings of Multiple Linear Regression Analysis. The finding of multiple linear regression analysis uses SPSS 15 software as it can be seen in Table 1.

Regarding to Table 1, not all independent variables are significant. Independent variables having significant value (significantly affect the failure of hot mix road timeline achievement in Tulungagung District) are Vehicle (X1), Work Environment (X2), and Quality Control (X9). On the other hand, the variables which are not significant are (not significantly affect the failure of hot mix road timeline in Tulungagung District) are Human Resources (X3), Work Implementation Method (X4), Equipment (X5), Land Condition (X6), Material (X7), and Financial (X8). 
$\mathrm{R}^{2}$ value is the determination coefficient which mainly measures how far regression model ability in describing the diversity of dependent variable (Y). In this study, it is found that the diversity of dependent variable $(Y)$ is .527 meaning that $52.7 \%$ affects the failure of hot mix road timeline achievement $(\mathrm{Y})$ in Tulungagung District. Moreover, $\mathrm{R}$ value which is the correlation explaining the closeness of relationship between independent variables $(X)$ and dependent variable $(\mathrm{Y})$ found in this study is .726.

Table 1 - Summary of Multiple Linear Regression Analysis Findings

\begin{tabular}{|c|c|c|c|c|}
\hline Variable & Standardize Coefficient $\beta$ & $t_{\text {count }}$ & p-value & Description \\
\hline Vehicle(X1) & 0.270 & 2.822 & 0.006 & Significant \\
\hline Work Environment (X2) & 0.210 & 2.141 & 0.036 & Significant \\
\hline Human Resources (X3) & -0.154 & -1.654 & 0.103 & Not Significant \\
\hline Work Implementation Method (X4) & -0.046 & -0.471 & 0.639 & Not Significant \\
\hline Equipment (X5) & -0.048 & -0.504 & 0.616 & Not Significant \\
\hline Land Condition (X6) & -0.148 & -1.647 & 0.105 & Not Significant \\
\hline Material (X7) & 0.074 & 0.804 & 0.425 & Not Significant \\
\hline Financial $(\mathrm{X} 8)$ & -0.167 & -1.816 & 0.074 & Not Significant \\
\hline Quality Control (X9) & 0.453 & 4.875 & 0.000 & Significant \\
\hline $\begin{array}{l}\alpha=0.05 \\
\mathrm{R}^{2}=0.527 \\
\mathrm{R}=0.726 \\
\text { F-count }=7.424 \\
\text { F-table }(0.05,9,60)=2.040 \\
p \text {-value }=0.000 \\
\text { t-table }(0.05,60)=2.000\end{array}$ & & & & \\
\hline
\end{tabular}

Sources: SPSS Analysis, 2017.

Moreover, to determine the dominant independent variable (factor) influencing the failure of hot mix road timeline, comparing standardized coefficient $\beta$ value of each independent variable (factor) toward $Y$ is carried out. As a result, the dominant variable is a variable which affects significantly and has the largest standardized coefficient $\beta$ value.

Based on Table 1, factor of Quality Control (X9) is the variable having the largest standardized coefficient $\beta$ value. It means the dominant factor in infector study on the failure of hot mix road timeline achievement in Tulungagung District is Quality Control Factor (X9). It shows that the failure of hot mix road timeline achievement is mostly affected by Quality Control Factor (X9). The positive standardized coefficient $\beta$ value indicates that the better Quality Control Factor (X9) is the greater achievement hot mix road timeline is.

\section{CONCLUSION AND SUGGESTIONS}

Regarding to the findings and discussion of this study, it can be concluded that:

$\mathrm{F}$ test shows that Vehicle (X1), Work Environment (X2), Human Resources (X3), Work Implementation Method (X4), Equipment (X5), Land Condition (X6), Material (X7), Financial (X8), and Quality Control (X9) affect simultaneously on the failure of hot mix road timeline achievement in Tulungagung District with $F_{\text {count }}=7.424>F_{\text {table }}=2.040$. On the other hand, partial t-test shows that factors that affect significantly on the failure of hot mix road timeline achievement are Quality Control (X9) with $t_{\text {count }}=4.875>t_{\text {table }}=2.000$, Vehicle $(X 1)$ with $t_{\text {count }}=$ $2.822>t_{\text {table }}=2.000$, and Work Environment $(X 2)$ with $t_{\text {count }}=2.141>t_{\text {table }}=2.000$.

The dominant factor affecting the failure of hot mix road timeline achievement in Tulungagung District is Quality Control (X9) with .453 as the coefficient $\beta$.

Strategies to overcome the problems in order to achieve hot mix road timeline achievement are:

- Controlling the materials used carefully during the work and testing the asphalt after the works finishes;

- Testing the asphalt should be carried out after the works finishes. 


\section{Suggestions:}

- To reach the project target planned, quality control factor of material should be considered well;

- Material testing to laboratory needs to be carried out in order to make the quality of materials used meets the standard quality;

- For future researchers, they should add additional variables, such as the correlation with government and pay more attention on indicators used so that it will be more applicative that can complete this study.

\section{REFERENCES}

1. Alik, A. A. (2006). Rekayasa Jalan Raya. Universitas Muhammadiyah Malang.

2. Alkass, S., \& Harris, F. (1991). Development of an integrated system for planning earthwork operations in road construction. Construction Management and Economics, 9(3), 263-289.

3. Bari, J. (2005). Development of a new revised version of the Witczak $E^{*}$ predictive models for hot mix asphalt mixtures(Doctoral dissertation, Arizona State University).

4. El-Rayes, K., \& Kandil, A. (2005). Time-cost-quality trade-off analysis for highway construction. Journal of construction Engineering and Management, 131(4), 477-486.

5. Epps, J. A. (2002). Recommended performance-related specification for hot-mix asphalt construction: Results of the WesTrack project (Vol. 455). Transportation Research Board.

6. Eriksson, J., Girod, L., Hull, B., Newton, R., Madden, S., \& Balakrishnan, H. (2008, June). The pothole patrol: using a mobile sensor network for road surface monitoring. In Proceedings of the 6th international conference on Mobile systems, applications, and services (pp. 29-39). ACM.

7. Foltz, R. B. (1996, June). Traffic and no-traffic on an aggregate surfaced road: Sediment production differences. In Proceedings of the seminar on environmentally sound forest roads and wood transport. June (pp. 17-22).

8. King, G. C., Stein, R. S., \& Lin, J. (1994). Static stress changes and the triggering of earthquakes. Bulletin of the Seismological Society of America, 84(3), 935-953.

9. Public Works Department of Directorate General of Highways. 1983. Standar Perencanaan Geometrik untuk Jalan Perkotaan. Jakarta. 